\title{
Growth and seasonal energetics of the Antarctic bivalve Laternula elliptica from King George Island, Antarctica
}

\author{
In-Young Ahn ${ }^{1, *}$, Jeonghee Surh ${ }^{2}$, You-Gyoung Park' ${ }^{2}$, Hoonjeong Kwon ${ }^{2}$, \\ Kwang-Sik Choi ${ }^{3}$, Sung-Ho Kang ${ }^{1}$, Heeseon J. Choi ${ }^{1}$, Ko-Woon Kim ${ }^{1}$, Hosung Chung ${ }^{1}$ \\ ${ }^{1}$ Polar Sciences Laboratory, Korea Ocean Research \& Development Institute (KORDI), Ansan, PO Box 29, \\ Seoul 425-600, Republic of Korea \\ ${ }^{2}$ Department of Food and Nutrition, Seoul National University, Sillim-dong, Kwanak-ku, Seoul 151-742, Republic of Korea \\ ${ }^{3}$ Department of Aquaculture, Cheju National University, Ara-1-dong, Cheju 690-756, Republic of Korea
}

\begin{abstract}
The Antarctic marine environment is characterized by extreme seasonality in primary production, and herbivores must cope with a prolonged winter period of food shortage. In this study, tissue mass and biochemical composition were determined for various tissues of the bivalve Laternula elliptica (King \& Broderip) over a $2 \mathrm{yr}$ period, and its storage and use of energy reserves were investigated with respect to seasonal changes in food level and water temperature. Total ash-free dry mass (AFDM) accumulated rapidly following phytoplankton blooms (with peak values immediately before and after spawning) and was depleted considerably during the spawning and winter periods. Most of the variation was in the muscle, gonads and digestive gland. Spawning peaked in January and February and caused considerable protein and lipid losses in the muscle, gonads and digestive gland. In winter (March to August), the muscle and digestive gland lost considerable mass, while gonad mass increased; this suggests that the muscle tissue and digestive gland serve as major energy depots for both maintenance metabolism and gonad development in winter. There were also marked year-to-year differences in the seasonal patterns of mass variation and reproduction. Overall, the relative and absolute tissue-mass values were positively correlated with chlorophyll concentration, and were not related to water temperature; thus, for the first time, this study clearly shows that food is an important factor governing growth and gonad maturation in this bivalve. It is also noteworthy that protein, constituting $\sim 75 \%$ of AFDM, served as the major energy reserve throughout the study, closely following the AFDM variation. In particular, during the winter months, protein comprised $>60 \%$ of AFDM loss, while lipids and glycogen served as minor $(<20 \%$ each) reserves. Protein loss was most substantial in the muscle tissue, which comprised half of the body tissue. Thus, protein use, with muscle tissues as a depot for protein reserves, may be a result of selective pressure on Antarctic marine herbivores undergoing a prolonged period of food shortage in winter.
\end{abstract}

KEY WORDS: Antarctic bivalve $\cdot$ Laternula elliptica $\cdot$ Growth $\cdot$ Energy reserve $\cdot$ Biochemical composition $\cdot$ Protein $\cdot$ Reproduction

Resale or republication not permitted without written consent of the publisher

\section{INTRODUCTION}

Primary production in the water column of Antarctic marine environments is extremely seasonal and is limited to a short period during the summer. In terms of energy balance, such a short primary production season may cause problems for marine herbivores, particularly for sedentary benthic filter-feeders that rely exclusively on primary producers for food. These organisms are expected to have developed strategies to deal with this problem. In fact, many Antarctic benthic marine herbivores show distinct seasonality in growth and reproduction (Clarke 1988, Urban \& Mercuri 1998, Peck et al. 2000, Brockington et al. 2001), which may be related to 
the overall seasonality of their environment, particularly food availability (Clarke 1988, 1996). However, experimental or field studies to support this hypothesis are lacking. Furthermore, few studies have been conducted to investigate the storage and use of energy reserves by these Antarctic organisms for the prolonged winter period of food limitation, which may last as long as 9 mo (Clarke et al. 1988, Clarke \& Leakey 1996).

The Antarctic soft-shelled clam Laternula elliptica (King \& Broderip) is endemic to the Antarctic; it is widely distributed in shallow waters around the Antarctic continent and adjacent islands. This deepburrowing, large $(\sim 110 \mathrm{~mm}$ in shell length; Ahn 1994) filter-feeder occurs in dense patches (several hundreds per $\mathrm{m}^{2}$ ) in shallow sheltered areas, and appears to play a key role in Antarctic nearshore marine ecosystems (Ahn 1993). Despite its wide distribution and abundance, this species has rarely been studied until recently, apparently due to difficulties in sampling and experimental manipulation in the field. To date, most studies have concentrated on distributional patterns or abundance (Stout \& Shabica 1970, Hardy 1972, Ahn 1994, Mercuri et al. 1998, Cattaneo-Vietti et al. 2000). While several studies have revealed a distinct seasonality in the growth, reproduction (Brey \& Mackensen 1997, Urban \& Mercuri 1998, Bigatti et al. 2001) and metabolism of L. elliptica (Brockington 2001), little work has been done to clarify the related environmental factors. Overwintering strategies also are largely unknown, although Brockington (2001) observed a significant reduction in the protein content of muscular tissues in one winter month as compared to one summer month, suggesting that a protein-based metabolism was used for winter survival.

In this study, tissue mass and major biochemical composition were determined for various tissues of Laternula elliptica over a 2 yr period. We investigated seasonal variations in relation to water-column chlorophyll, seawater temperature, and reproductive condition. The results of this comprehensive study present the first direct evidence that food availability is a key factor governing seasonal patterns in the growth and reproduction of L. elliptica. Furthermore, the storage and use of major energy reserves in different tissues were examined in an attempt to understand the energetic strategies used by this species to cope with a prolonged winter period of food shortage in the Antarctic marine environment.

\section{MATERIALS AND METHODS}

Environmental conditions and sample collection. Laternula elliptica is present at very high densities $\left(\sim 170\right.$ ind $\left.\mathrm{m}^{-2}\right)$ at depths of 15 to $30 \mathrm{~m}$ near King
Sejong Station $\left(62^{\circ} 13^{\prime} \mathrm{S}, 58^{\circ} 47^{\prime} \mathrm{W}\right)$ in Marian Cove (Ahn 1993, Ahn et al. 2001). Marian Cove is a small, fjord-like embayment located in NE Maxwell Bay, which is characterized by a deep U-shaped basin with a maximum water depth of $\sim 100 \mathrm{~m}$. Surface water freezes in winter and melts in summer, but a variable cover of drifting ice occurs during most of the year. Seawater temperature varies seasonally, from a maximum of ca. $1.7^{\circ} \mathrm{C}$ in February to a minimum of ca. $-1.7^{\circ} \mathrm{C}$ in August; salinity ranges from ca. 32 to $35 \mathrm{psu}$ (Kim 1996, Kang et al. 1997, KORDI 1999). Further details of the hydrographic features and other environmental conditions of this area have been described elsewhere (Chang et al. 1990, Ahn 1997a, Kang et al. 1997, Ahn et al. 2000). During the present investigation, water temperature, total chlorophyll, and salinity data were obtained from a long-term monitoring program conducted at the station (KORDI 1999). Total chlorophyll (chlorophyll $a+$ phaeopigments) was determined in vivo using a fluorometer (Turner 10-AU-005). Water temperatures and salinity were measured using a conductivity meter (YSI 610-D).

Laternula elliptica were hand-collected by SCUBA divers from depths between 20 and $30 \mathrm{~m}$. Sampling was conducted at 1 to 2 mo intervals between January 1998 and January 2000, except from June to October 1998 and March to June 1999, when samples could not be collected due to harsh weather conditions. At each sampling, 20 to 30 clams were collected; they were frozen rapidly at $-20^{\circ} \mathrm{C}$ and stored for up to $12 \mathrm{mo}$ at the station before being transported on dry ice to Korea. Transported samples were stored at $-70^{\circ} \mathrm{C}$ until they were analyzed. To evaluate reproductive condition, several dozen additional clams were collected during each sampling and preserved in $10 \%$ buffered formalin for later histological analysis.

Sample preparation for biochemical analysis. For each sampling date, 10 to 13 adult clams in a relatively restricted size range (66 to $89 \mathrm{~mm}$ shell length, SL, the longest shell dimension) were used to determine tissue mass and biochemical composition. Frozen clams were partially thawed and dissected into 5 tissue compartments (muscle, gonads, digestive gland, gill, and the remaining tissue) following the methods described by Ahn et al. (2000). Muscle tissue consisted mostly $(>80 \%)$ of the siphon and the rest of the mantle. The adductor muscle of Laternula elliptica is vestigial, and it was therefore included in the remaining tissue along with the foot and kidney. Wet weights of the excised tissues were summed to calculate the total tissue wet mass for each individual clam. The excised tissues were then pooled for each tissue compartment and freeze-dried for ca. $48 \mathrm{~h}$. The dried tissues were then ground to a fine powder in a mortar and used to determine the biochemical composition of each individual tissue compartment. 
Proximate analysis of major biochemical composition. Lipids were extracted following the procedures of Folch et al. (1957), and total lipid content was quantified gravimetrically. Protein was estimated as total $\mathrm{N}$ content, using a standard micro-Kjeldahl procedure, with 6.25 as the multiplication factor to obtain protein figures from the observed values for total nitrogen. Glycogen (glucose included) was determined enzymatically using the methods described by Keppler \& Decker (1984), with minor modifications for use in microplate readers (Saborowski \& Buchholz 1996). Purified glycogen from mussel tissue (Sigma) was used as the standard. Recovery rates of the standard glycogen ranged from 94 to $110 \%$ in each trial. Ash was determined after incineration at $500^{\circ} \mathrm{C}$ for $24 \mathrm{~h}$. All measurements were run in triplicate. The protein, lipid, and glycogen content of each tissue was calculated as follows: content of a constituent in the tissue (in $\mathrm{mg})=(\%$ constituent of dry mass $\times$ dry mass of the tissue in $\mathrm{mg}$ ) $/ 100$.

Calculation of tissue indices. We used 3 indices in this study. The condition index (CI) indicates the overall tissue growth, and was calculated using the following formula: $\mathrm{CI}=$ (ash-free dry mass, AFDM of total tissue in $\mathrm{mg}) /(\mathrm{SL}$ in $\mathrm{mm})$. The condition index of marine bivalves is commonly expressed as a proportion of internal shell-cavity volume (Gosling 1992). In the case of Laternula elliptica, however, accurate shell volume could not be determined, as the shell has a large posterior gape through which the huge siphons protrude.
In many cases, the shells of the collected clams were also found to be partially broken, apparently because the shell is very thin and fragile. Shell length, rather than shell volume or weight, was therefore used in calculating the CI of L. elliptica. The hepatosomatic index (HSI $=$ AFDM of digestive gland $\times 100 /$ AFDM of total tissue), whereby the mass of the digestive gland (equivalent to the liver in fishes) is related to total body mass, served as an index of nutritive state (Saborowski \& Buchholz 1996). The gonad index (GI = AFDM of gonad $\times 100 /$ AFDM of total tissue) was used to assess reproductive condition.

Standard clam. Despite the use of a restricted size range, there were some size differences among the clams collected on different sampling dates (Table 1). Therefore, the tissue mass values on each sampling date were normalized to those of a $75.5 \mathrm{~mm}$ SL clam; this was the approximate mean shell size of the clams used in this study. The accumulation and depletion of the major biochemical constituents were determined for this standard clam (Table 1). Wet tissue mass of a $75.5 \mathrm{~mm}$ SL Laternula elliptica was estimated based on the regression analysis of wet tissue mass - SL of individual clams. Dry tissue mass and the absolute amounts of the major biochemical components for each tissue compartment of the standard clam were then calculated based on the data obtained from the actual biochemical analysis, and their variations were determined over the study period. The AFDM values of the standard clam were highly correlated $\left(\mathrm{r}^{2}=0.95, \mathrm{p}<0.001\right)$ with the condition indices

Table 1. Laternula elliptica. Shell size and mass values of clams used for biochemical analysis. Tissue wet mass (TWM) values with superscript ${ }^{a}$ were normalized for $75.5 \mathrm{~mm}$ shell length (SL) clam based on regression analysis of SL and TWM relations of individual clams (about 20 clams were used for each regression analysis); remaining TWM values were those of standard clam, as the mean SL ( 74.7 to $76.2 \mathrm{~mm}$ ) of measured clams approximated the standard size. Tissue dry mass (TDM) and ash-free dry mass (AFDM) values of the standard clam were then calculated based on \% water and \%AFDM data from biochemical analysis

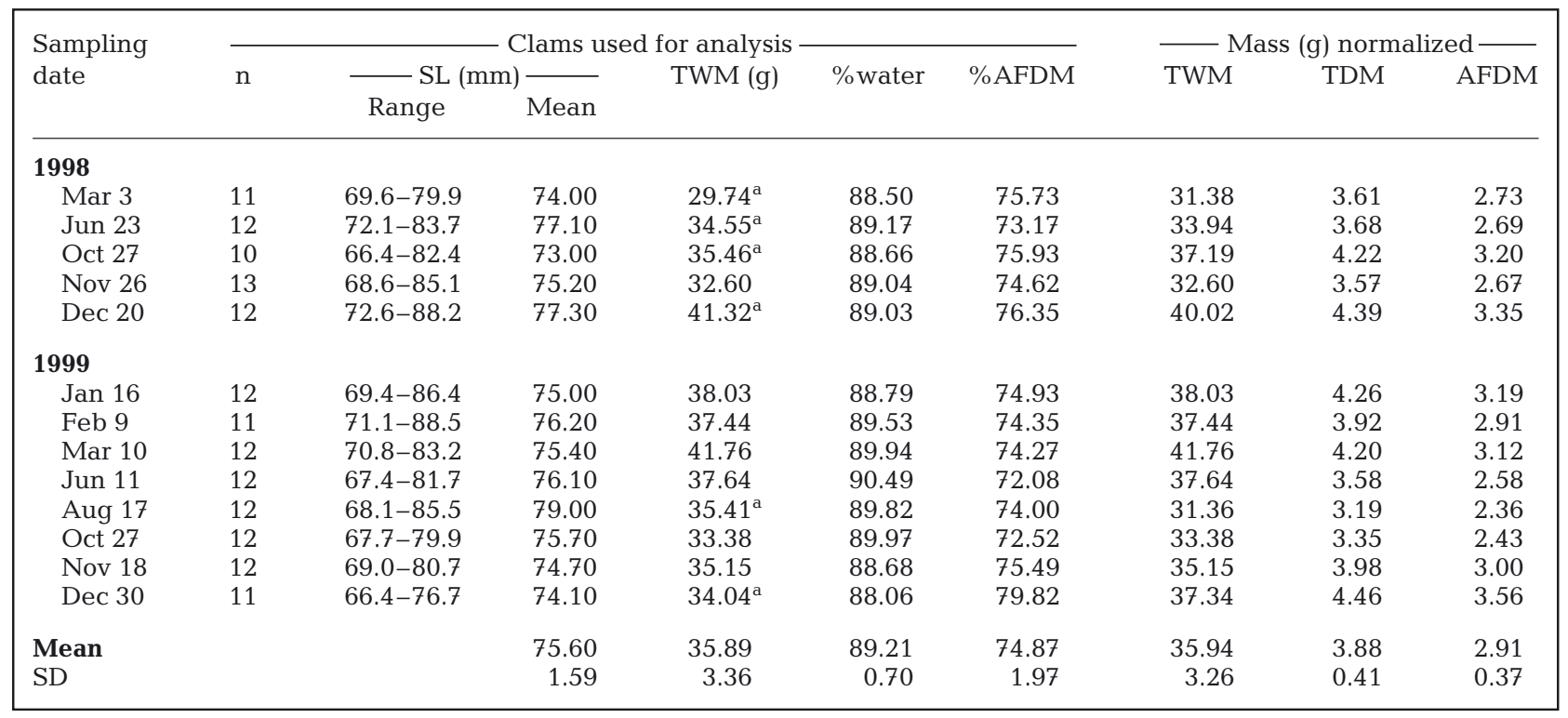


actually measured on each corresponding sampling date, indicating a good and reliable normalization of the tissue-mass values for the standard clam.

Histological analysis to determine reproductive condition. Cross-sections of the gonads were prepared for histological examination as described by Ahn et al. (2000). Laternula elliptica is hermaphroditic, with female and male gonads fused together and visually indistinguishable. The reproductive status of each clam was based on the microscopic examination of female gonadal parts and was categorized as resting (Stage I), developing (Stage II), fully developed (Stage III), spawning (Stage IV), spent (Stage V), or absorbing (Stage VI). The duration and termination of spawning were determined by the presence or absence of mature oocytes (Beninger \& Lucas 1984).

\section{RESULTS}

\section{Water temperature and total chlorophyll}

Seasonal variations in water temperature and total chlorophyll concentration in surface seawater are presented in Fig. 1A. A pronounced seasonal cycle was evident in temperature, with a maximum $\left(+1.8^{\circ} \mathrm{C}\right)$ in February and a minimum in August $\left(-1.8^{\circ} \mathrm{C}\right)$ in both years. Occasionally, however, seawater temperature fell during the summer months due to the presence of floating ice or the inflow of glacial meltwater from surrounding ice fields or submerged glaciers. Seawater temperature data at depths of 20 to $30 \mathrm{~m}$, where Laternula elliptica were collected, were not available during the investigation period. According to data from previous years, however, seawater temperatures at a depth of $20 \mathrm{~m}$ show little difference compared to surface water, except during massive inflows of glacial meltwater (Chang et al. 1990, Kim 1996). Salinity also showed distinct seasonal variation, with maximum levels in winter and minimum levels in summer, although the magnitude of the variation (32.6 to $34.3 \mathrm{psu}$ ) was much smaller than that of water temperature.

Total chlorophyll also showed distinct seasonality, and the weekly mean of total chlorophyll concentration varied widely from $<0.2$ to $2.7 \mu \mathrm{g} \mathrm{l}^{-1}$. The seasonal pattern of watercolumn chlorophyll, however, was not as cyclic as that of water temperature. An un- usual microalgal bloom (1.07 to $12.2 \mathrm{\mu g} \mathrm{l}^{-1}$ with a mean of $3.0 \mathrm{\mu g} \mathrm{l}^{-1}$ total chlorophyll) persisted from late September to early October 1998 (Fig. 1A). Microsized diatoms dominated the bloom, and the explosive production of these diatoms may have been associated with the breakup of sea ice that occurred at the time (KORDI 1999). This
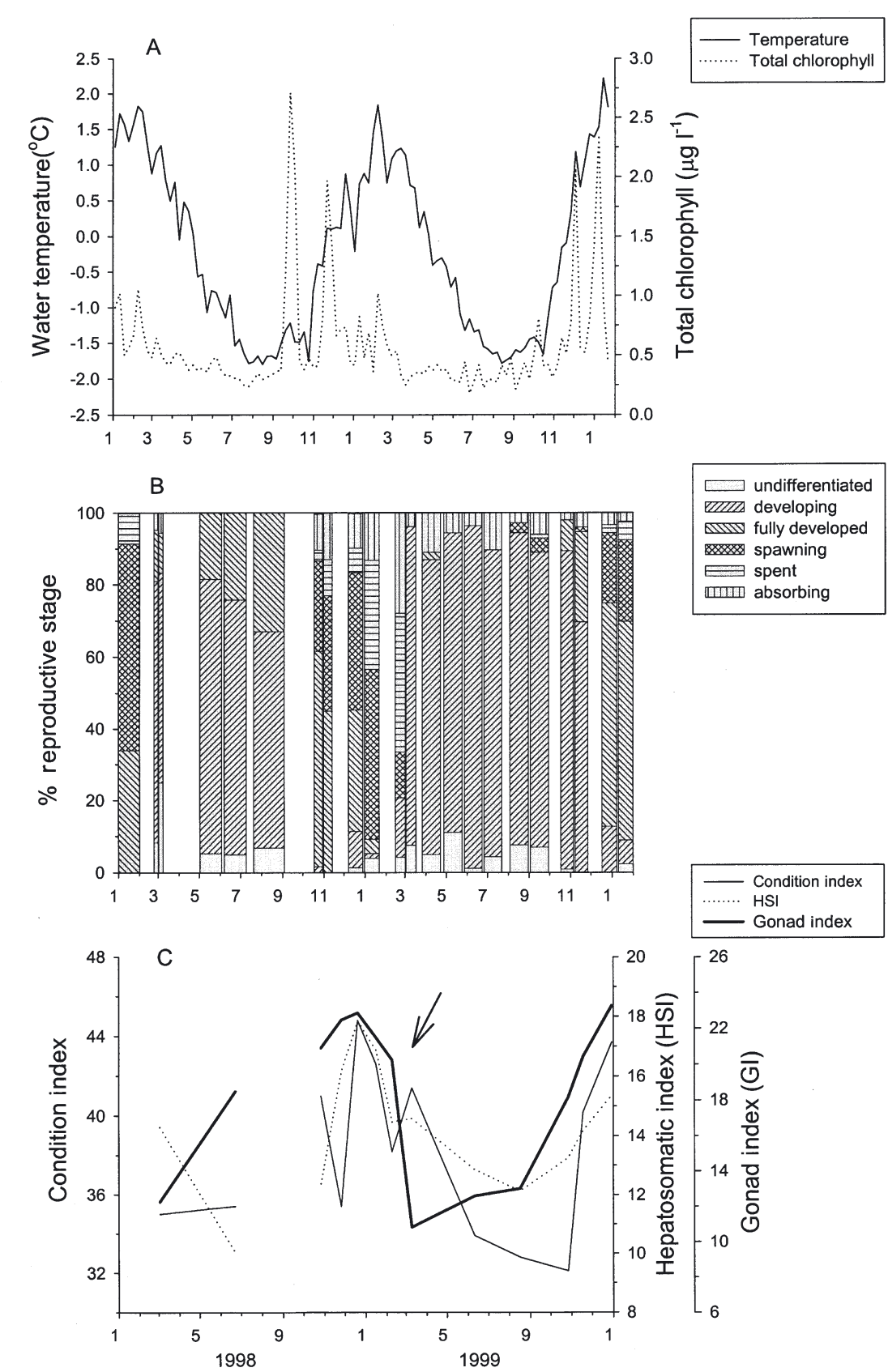

Fig. 1. Laternula elliptica. Seasonal variations in (A) water temperature and total chlorophyll, (B) reproductive status, and (C) tissue indices of clams used for analyses. Temperature and chlorophyll data are weekly means of daily measurements obtained during a long-term monitoring program at King Sejong Station (KORDI 1999). See text for calculation of indices. Arrow indicates major spawning event. Here and in subsequent figures, nos. on abscissas indicate months of year 
early spring bloom was rather unusual, because watercolumn blooms in this area generally begin no earlier than November (Kang et al. 1997, 2002, KORDI 1997, 2000). Moreover, no other bloom in the study period was as intense as this one in early spring.

Daily water temperatures and total chlorophyll concentrations were averaged for each period between 2 successive clam-sampling dates; the daily values were summed up and divided by the number of days for each period. The average daily values were then correlated with the tissue indices and also with the absolute biochemical contents obtained at the end of the period. Salinity, which showed slight seasonal variations, was not considered in the correlation analyses.

\section{Reproductive cycle and tissue indices}

Seasonal variation in the reproductive condition of Laternula elliptica is presented in Fig. 1B. Microscopic examination of the gonads showed that the collected clams contained oocytes of various sizes, including mature oocytes, throughout the year. The percentage of fully developed and mature oocytes $(\sim 200 \mu \mathrm{m}$ in diameter; Bigatti et al. 2001), however, gradually increased during the winter period, and most clams were fully developed and spawning by the following summer months (December to February). In the 1998/1999 season, most $L$. elliptica were found to have spawned in January and February, although some individuals spawned as early as October 1998. For the $1997 / 1998$ and 1999/2000 seasons, the entire duration of spawning was not observed. However, $>80 \%$ of clams collected in January of 1998 and 2000 had fully developed gonads or were in the spawning stages, indicating some consistency in spawning time.

The relative size of the gonads, expressed as the gonad index (GI), varied in accordance with oocyte development and continued to increase during the winter (Fig. 1C). After the GI peaked (22.9) in late December of 1998, it dropped sharply in January and February 1999, reaching its lowest value in early March (10.8). However, we found significant interannual variation in both oocyte development and gonad mass growth, particularly during the winter months. Oocyte development and gonad mass increase proceeded at much slower rates from March to August 1999 than in the corresponding months of 1998. After September, however, gonad mass began to increase rapidly and, in December 1999, the GI value (23.3) approximated that recorded in December 1998.

The tissue indices CI and HSI increased rapidly in early summer to a peak level that coincided with peak GI (Fig. 1C). As the GI dropped sharply at the onset of spawning, CI and HSI also declined concomitantly, but a new peak of both indices was achieved again in early March, when GI was at its lowest recorded value. Thereafter, both indices decreased steadily during the winter of 1999. As in gonad development, we recorded significant interannual variation in the CI value, particularly during the winter periods. While the CI value changed only slightly from March to July 1998, it declined substantially during the corresponding months of 1999. HSI values, on the other hand, showed a significant reduction during both winters. GI, HSI and CI were shown to correlate positively with total chlorophyll concentration (Table 2). None of these indices, however, was related to water temperature.

\section{Proximate biochemical composition of tissues}

Muscle tissue constituted the largest fraction (ca. $56 \%$ of total tissue dry mass, TDM), followed by the gonads (18\% of total TDM) and the digestive gland (13\% of total TDM). The gill and remaining tissue comprised 6 and $7 \%$, respectively. The most distinct seasonal variation in percentage mass was found in the gonads (11.7 to $23.1 \%)$, followed by the digestive gland $(9.8$ to $16.3 \%$ ). The percentage mass of the gonads and digestive gland showed the highest values in summer prior to spawning and the lowest values during the winter, whereas muscular parts (48.4 to $61.9 \%$ ) showed the opposite trend.

Seasonal variations in protein, lipid, and glycogen levels of the major tissues are shown in Fig. 2, expressed as a percentage of AFDM. Protein, lipids, and glycogen constituted $\sim 90 \%$ of the AFDM. Protein was the major organic constituent ( $>50$ to $87 \%$ AFDM) in all tissues. Protein levels were highest in muscle tissue (78 to $87 \%$ AFDM with a mean of $82 \%$ ), and seasonal variation was apparent in the muscle, gonads and digestive gland. Lipid levels were highest in the gill (16 to 20\% AFDM with a mean of $18 \%$ ), followed by the digestive gland (12 to $15 \%$ AFDM with a mean of $13.5 \%$ ) and gonads (9.3 to $13 \%$ AFDM with a mean of $11 \%$ ), but a distinct pattern of variation was found only in the gonads, apparently associated with spawning. While glycogen

Table 2. Laternula elliptica. Partial correlation coefficients between temperature, total chlorophyll and tissue indices of clams used for analysis. CI: condition index; HSI: hepatosomatic index; GI: gonad index. Significance: ${ }^{* *} 0.001<\mathrm{p}<$ $0.01{ }^{*} 0.01<\mathrm{p}<0.05$

\begin{tabular}{|lcc|}
\hline & Temp & Total chl \\
\hline Temp & & 0.354 \\
CI & 0.116 & $0.659^{*}$ \\
HSI & 0.095 & $0.696^{* *}$ \\
GI & -0.426 & $0.596^{*}$ \\
\hline
\end{tabular}



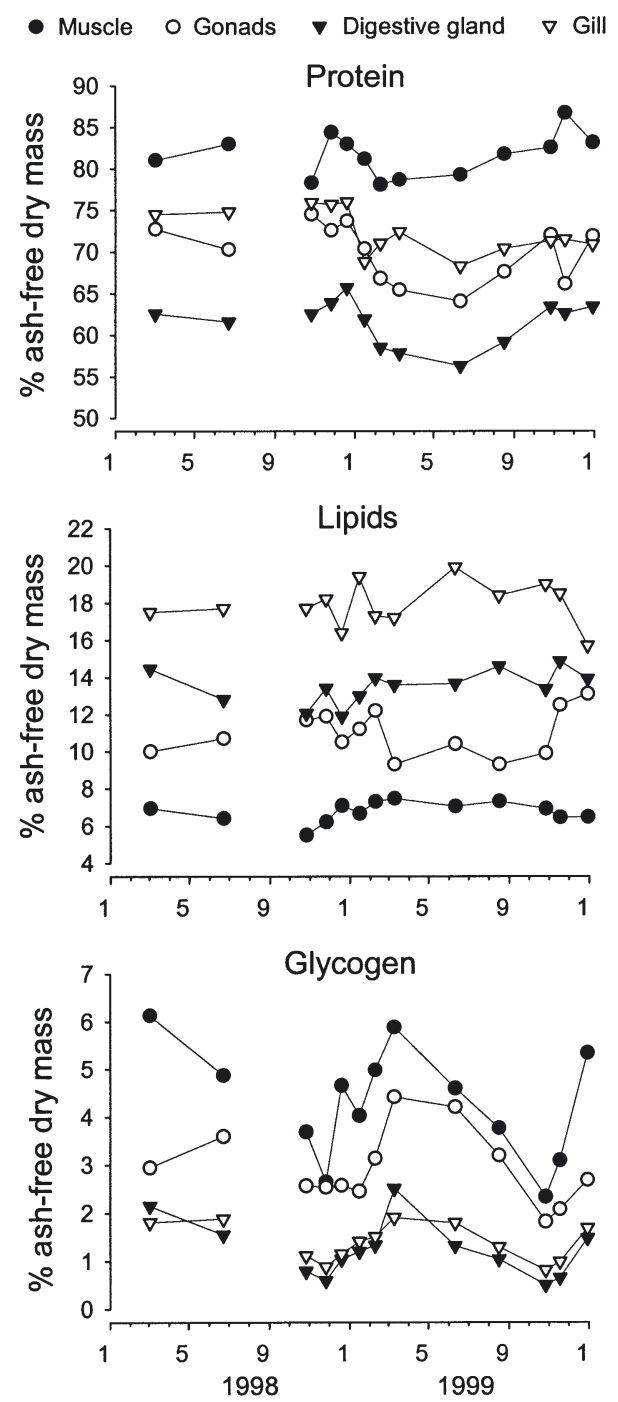

Fig. 2. Laternula elliptica. Seasonal variations in percentage levels of major organic constituents in various tissues

exhibited distinct seasonal variation in all major tissues, it remained at very low levels ( $<7 \%$ AFDM) throughout the study. For whole-body tissues, the composition remained broadly similar throughout the investigation: protein, lipids, glycogen, and ash averaged $76 \%$ AFDM ( $\approx 7 \%$ TDM $), 9.3 \%$ AFDM $(7.0 \%$ TDM $), 3.4 \%$ AFDM $(2.5 \% \mathrm{TDM})$, and $25 \%$ of TDM, respectively.

The largest portions of protein (52 to $67 \%$ ), lipids (31 to $51 \%$ ), and glycogen (60 to $79 \%$ ) were retained in the muscles, which constituted the largest fraction of the total tissue. Significant amounts of these organic constituents were also retained in the gonads and digestive gland; during the reproductive season, gonads contained $\sim 22 \%$ of total protein and $\sim 30 \%$ of total lipid. The gills, which had the highest lipid levels despite the small mass fraction, also contained a relatively large portion of lipids (9.3 to $13.6 \%$ of total body lipids with a mean of $11.4 \%$ ).

\section{Seasonal variations in the absolute amounts of major biochemical constituents in various tissues}

Seasonal variations in the AFDM and in the absolute amounts of major organic constituents of a standard 75.5 mm SL Laternula elliptica are illustrated in Fig. 3. Significant variation was observed in all tissues, notably in the muscle, gonads, and digestive gland. Protein showed the largest amount (>60\%) of AFDM variation in all tissues, closely following the variation in AFDM. Lipid contents also showed a significant variation in all tissues, particularly in the gonads and digestive gland. Glycogen remained at very low levels $(<7 \%$ of AFDM) throughout the study, and a distinct seasonal variation in glycogen content was found only in the muscle tissue.

Spawning, which occurred from late December through February 1999, caused a considerable decline in organic constituents among all major tissues at its onset. In the gonads, the absolute amounts of protein and lipid continuously decreased throughout the entire spawning period, reaching their annual minimum near the end of the spawning period (Fig. 3). In all the other tissues, however, the drastic loss of the organic constituents at the onset of spawning was followed by rapid increases in these constituents during the rest of the spawning period, reaching a new peak at the end of the spawning period. Throughout the spawning period, the highest amount of AFDM $(\sim 50 \%)$ was lost from the gonads, followed by the muscle (24\%), and digestive gland (22\%). Lipid loss was also significant in the gill (12\% of total lipid loss), whose lipid levels were highest among the tissues. Protein and lipid constituted approximately 80 and $12 \%$, respectively, of the total AFDM loss. Depletion of glycogen was detectable only in muscle tissues.

In the winters of both 1998 and 1999, ca. $90 \%$ of protein, lipid, and glycogen losses occurred in the muscle tissue and digestive gland (Fig. 3, Table 3). Protein constituted $\sim 60 \%$ of total AFDM loss. Lipids and glycogen constituted 10 to $18 \%$ and 10 to $15 \%$, respectively. Total tissue-mass reduction was substantial during the early winter months (March to June) of 1999 ( 24\% of total AFDM), while it was only slight during the corresponding months of 1998, being apparently masked by the substantial increase in gonad mass (Table 3). Despite the year-to-year differences in total mass reduction in the winter, the digestive gland consistently showed a substantial reduction during the winter months of 1998 and 1999.

The AFDM of total tissue, gonads, digestive gland and gill were positively correlated with chlorophyll concentration, while none of these values showed a distinct relation with water temperature (Table 4). Despite the largest amounts of mass variation, the muscle tissue did not show any significant relations with chlo- 

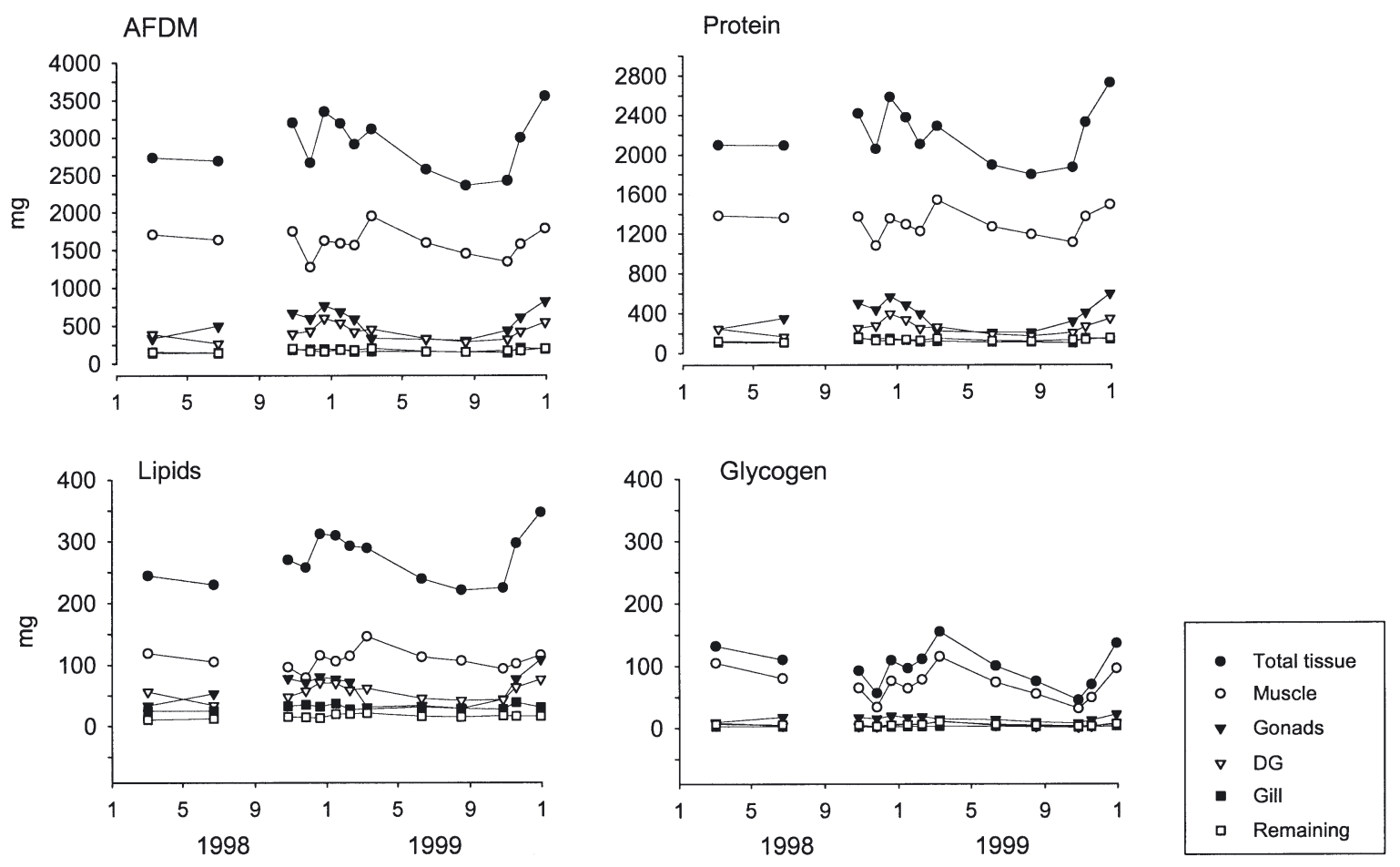

Fig. 3. Laternula elliptica. Seasonal variations in absolute amounts of AFDM and major organic constituents in various tissues of a standard $75.5 \mathrm{~mm}$ shell length clam. DG: digestive gland

rophyll. This is probably because the percentage mass increases or decreases were relatively small in the muscle $(<30 \%$ of the muscle tissue mass). In contrast, they were $\sim 60 \%$ in the gonads and the digestive gland.

\section{DISCUSSION}

\section{Influence of food availability on tissue growth and reproduction}

Seasonal patterns were evident in the tissue mass and reproductive cycles of Laternula elliptica. Microscopic examination of the gonads of $L$. elliptica reveal- ed that this species becomes reproductively mature just before the annual summer phytoplankton bloom and spawns before the end of the summer. Spawning peaked in January and February, which was also evidenced by the $50 \%$ drop in the gonad index. Total tissue mass increased rapidly during the summer months, with peak values immediately before and after spawning, and gradually decreased over the ensuing winter months. The overall seasonal patterns were similar to the patterns previously reported for this species at Potter Cove, a small bay several kilometers away from the study area (Urban \& Mercuri 1998).

Seasonal changes in the tissue mass and the biochemical composition of marine bivalves are closely

Table 3. Laternula elliptica. Comparison of reduced (-) and increased (+) AFDM values in different tissues of a 75.5 mm SL clam in winter months of 1998 and 1999. Protein comprised $>50 \%$ of AFDM lost in winter period of 1998 and $>70 \%$ in that of 1999 .

Values in parentheses are amounts of protein lost from the 2 major energy sources

\begin{tabular}{|c|c|c|c|c|c|c|}
\hline \multirow[t]{2}{*}{ Tissue } & \multicolumn{2}{|c|}{ Mar 3-Jun 23, 1998 (112 d) } & \multicolumn{2}{|c|}{ Mar 10-Jun 11, 1999 (93 d) } & \multicolumn{2}{|c|}{ Jun 11-Aug 17, 1999 (67 d) } \\
\hline & $\mathrm{mg}$ & $\%$ loss & $\mathrm{mg}$ & $\%$ loss & $\mathrm{mg}$ & $\%$ loss \\
\hline Muscle & $-69(21)$ & 34 & $-355(270)$ & 66 & $-144(78)$ & 66 \\
\hline Digestive gland & $-124(80)$ & 60 & $-123(76)$ & 23 & $-45(17)$ & 21 \\
\hline Gonads & +162 & - & -13 & 2 & -17 & 8 \\
\hline Gill & -2.4 & 1 & -5.9 & 1 & -3.0 & 1 \\
\hline Remaining tissue & -10 & 5 & -43 & 8 & -8.7 & 4 \\
\hline Total & -43 & 100 & -539 & 100 & -217 & 100 \\
\hline
\end{tabular}


Table 4. Laternula elliptica. Partial correlation coefficients between water temperature and total chlorophyll, and various tissue AFDM values of a $75.5 \mathrm{~mm}$ SL clam. Significance: ${ }^{* * *} \mathrm{p}<0.001 ;{ }^{* *} 0.001<\mathrm{p}<0.01 ;{ }^{*} 0.01<\mathrm{p}<0.05$

\begin{tabular}{|lcccccc|}
\hline Parameter & Total tissue & Muscle & Gonads & Digestive gland & Gill & Remaining tissue \\
\hline Temp & 0.171 & 0.480 & -0.316 & 0.168 & -0.350 & 0.038 \\
Total chl & $0.699^{* *}$ & 0.143 & $0.688^{* *}$ & $0.804^{* * *}$ & $0.588^{*}$ & 0.275 \\
\hline
\end{tabular}

linked to changes in food availability and temperature. In Antarctic waters, however, it is still unclear whether water temperature or food is the key factor controlling the growth; while the amplitude of seasonal variation is much greater for primary production than for water temperature, both factors tend to vary simultaneously. Recently, Brey \& Mackensen (1997), using the records of stable isotope ratios in shell carbonate, demonstrated that shell growth occurs largely in summer: both $\delta \mathrm{O}^{18}$ and $\delta \mathrm{C}^{13}$ values were lower in the wider bands formed in spring and summer, i.e. the warmer and productive period. Brey \& Mackensen (1997), however, could not differentiate one variable (food) from the other (temperature). In the present study, fortunately, the rise and decline in total chlorophyll level in the surface water was not completely in phase with the temperature cycle; this allowed differentiating the effect of food level from that of temperature.

The positive correlations in the relative tissue indices and the absolute amounts of AFDM values with chlorophyll concentrations of the ambient seawater (Tables 2 \& 4) clearly show that food availability is an important factor governing the growth of Laternula elliptica. Furthermore, none of the tissue indices or absolute tissue-mass values was correlated with temperature, and rapid mass increase occurred even during the early summer (October to December) of 1998, when the water temperature was still very low $\left(<0.5^{\circ} \mathrm{C}\right)$; this strongly suggests that this bivalve should have the potential to grow rapidly irrespective of low temperatures, provided that food is available in sufficient quantities.

The results of this study substantiate the previous concept that Laternula elliptica grows rapidly during summer and maximizes food resources that are in sufficient supply; this may have developed as a response to the extremely seasonal food availability in the Antarctic marine environment. Based on the results of several experimental studies (Ahn 1993, Ahn \& Shim 1998), Ahn (1997b) suggested that a high feeding rate with reduced metabolic rates would enhance growth during the summer and would lead to high growth rates. Moreover, this bivalve population seems to be periodically eliminated from bottom substrates by grounded icebergs; shell fragments were frequently observed by divers at depths as deep as $30 \mathrm{~m}$. From an evolutionary viewpoint, a moderate to high turnover (growth) rate would therefore be necessary to sustain the high biomass of this bivalve species in shallow Antarctic waters. In addition, both the gonad index and the absolute amount of gonad AFDM showed a significant variation as a functionn of chlorophyll concentration. This suggests that food availability is also an important factor regulating the size of gonad mass.

\section{Interannual variability}

While this study covered only a 2 yr period, a significant interannual variation was observed in tissuemass cycles and gonad development, notably in the winter. Total tissue-mass reduction was substantial during the early winter months (March to June) of 1999 ( $24 \%$ of total AFDM), but was only slight during the corresponding months of 1998 (Table 3). Oocyte development and gonad mass increases were also much slower during the winter months of 1999. The positive correlations in the mass of total tissue, gonads and digestive gland to the chlorophyll concentrations (Table 4) indicate that the natural population probably underwent a more severe food shortage during the winter of 1999.

Marked interannual variability in the timing and magnitude of water-column production has previously been reported from the study area (Kang et al. 1997, KORDI 1997, 2000) and from other Antarctic nearshore waters (Clarke et al. 1988, Clarke \& Leakey 1996). This implies that the severity and duration of winter starvation could vary from year to year for sedentary benthic herbivores. In shallow polar waters, a substantial portion of the water-column production sinks to the bottom and is thus made available to benthic herbivores (Clarke 1988, Grebmeier \& Barry 1991). In this study, shortly after the spring bloom (mean of $3.0 \mu \mathrm{g} \mathrm{l}^{-1}$ total chlorophyll) from late September to early October 1998, a distinct pulse of sedimentation of organic carbon (137 $\mathrm{mg} \mathrm{C} \mathrm{m}^{-2} \mathrm{~d}^{-1}$ ) was detected in trapped sediment from early October through mid-November 1998 (Shim 2001). This unusually early water-column bloom apparently supplied a considerable amount of food flux to benthic herbivores, consequently ameliorating food limitation during that period. It is noteworthy that the total AFDM of the standard clam was $>30 \%$ higher in late October 1998 than in late October of 1999, 
apparently as a result of the intense spring bloom in 1998. The early spawning by some clams in October 1998 was also probably associated with the bloom; this may imply some flexibility in the reproductive ecology of this species, depending on food availability. In contrast, from early October through mid-November 1999, mean total chlorophyll concentration and organic carbon flux were only $0.37 \mathrm{mg} \mathrm{l}^{-1}$ and $\sim 60 \mathrm{mg} \mathrm{C} \mathrm{m}^{-2} \mathrm{~d}^{-1}$, respectively (Shim 2001). Thus, overlying watercolumn production probably plays a significant role in determining the overall food availability for shallowwater benthic herbivores such as Laternula elliptica, although Antarctic nearshore waters seem to provide alternative food sources such as benthic diatoms (Ahn et al. 1997).

Interannual variation has previously been reported for various biological aspects of some other Antarctic benthic invertebrates (Dayton 1989, Stanwell-Smith \& Clarke 1998, Clarke 2001). Although seasonality concurrent with solar radiation is a key feature of the Antarctic marine ecosystem, it is now recognized that interannual or long-term variability of other physical processes, such as the extent of sea ice, also exerts a profound influence on primary production and consequently biological processes at higher trophic levels (Dayton 1989, Murphy et al. 1995, Clarke 2001).

\section{Biochemical composition and energy reserves of tissues}

Protein comprised the largest fraction (>50 to $87 \%$ ) of AFDM in all tissues (Fig. 2) and served as the major energy reserve (>60\%: Fig. 3). Lipids (5.5 to $20 \%$ of AFDM) and glycogen (0.5 to $6.1 \%$ of AFDM) constituted minor fractions, even during the growth and reproductive seasons. The lipid levels of the various tissues in the reproductive season were similar to those reported in a previous study on this species (Ahn et al. 2000). This situation is quite different from that of many temperate bivalves, which accumulate lipids or glycogen during the growing season and utilize them for reproduction and maintenance metabolism during the rest of the year. Lipid levels of 10 to $>18 \%$ of TDW have frequently been reported for temperate bivalves during the reproductive season (De Moreno et al. 1976, Beukema \& De Bruin 1977, Pollero et al. 1979, Zandee et al. 1980, Klingensmith \& Stillway 1982, Davis \& Wilson 1983, Wenne \& Polak 1989). Glycogen levels comprise up to 60 to $70 \%$ of protein levels (or up to $35 \%$ of TDM) in other bivalves during the growing season (De Zwaan \& Zandee 1972, Beukema \& De Bruin 1977, Zandee et al. 1980, Gabbott 1983). Equivalent values for Laternula elliptica in this study were only $\sim 8$ and $\sim 3 \%$ of TDM for lipids and glycogen, respectively.
Such low levels suggest that lipids and glycogen do not play a major role in energy metabolism.

Low lipid levels have been reported for a wide variety of arctic benthic invertebrates, herbivores in particular (Clarke \& Peck 1991). Very few data, however, are available for Antarctic benthic invertebrates, resulting in a patchy picture. Yet, no benthic species has been shown to synthesize the large stores of lipids (wax esters) so characteristic of zooplankton. It appears that Antarctic benthic invertebrates in general have moderate or low levels of lipids in their tissues, and lipid storage seems mainly associated with reproduction (Pearse \& Giese 1966a,b, Clarke 1983, 1984, Peck et al. 1987). The role of lipids in Laternula elliptica, however, seems to vary among the body organs. The fact that the highest lipid levels were found in L. elliptica gills was unusual, considering that the highest lipid levels in most temperate bivalves are in the gonads, digestive glands, or mantle (De Moreno et al. 1976, Pieters et al. 1980, Zandee at al. 1980, Wenne \& Polak 1989). The lipid stores in the gills were completely depleted during the spawning period, suggesting that lipids stored in the gill are used mainly in reproduction. On the other hand, lipid stores in the muscle and digestive gland were depleted during both the spawning and winter periods, indicating that lipids in these organs serve as energy substrates for winter metabolism. Ahn et al. (2000) found the largest triacylglycerol (TAG) deposit $(\sim 38 \%$ of total body TAG) in the L. elliptica siphon, which comprised $\sim 80 \%$ of the muscular tissue, and suggested a potential role of lipid deposits in the siphon as an energy reserve for the winter starvation period. In the present study, during the 1999 winter period, the amount of lipid lost from the muscle tissue comprised ca. $54 \%$ of the total body-lipid reduction and ca. $5 \%$ of the total body-AFDM loss for that period.

Low carbohydrate levels seem to be common among various Antarctic invertebrates, including the bivalve Limatula hodgsoni $3.3 \%$ of TDW: Pearse \& Giese 1966b, Peck et al. 1987). Carbohydrate (mainly glycogen) levels represent storage of energy reserves in the tissues of marine mollusks and other invertebrates, varying widely as a function of environmental and physiological conditions (Gabbott 1983). However, it is uncertain whether the low lipid and carbohydrate levels found in these Antarctic benthic herbivores are attributable to geographical differences. The roles of lipids and carbohydrates warrant further investigation.

\section{Storage and use of energy reserves in tissues}

Most of the seasonal variations in the absolute amounts of protein, lipids, and glycogen were found in the muscle, gonads, and digestive gland, which to- 
gether retained ca. $90 \%$ of the total body energy substrates. The seasonal variation in these tissues was very similar to the relative tissue indices (Fig. 1C). Gonad mass was correlated with the reproductive cycle, and spawning caused a steep decline in the absolute amount of protein and lipids. On the other hand, stores in the muscle and digestive gland were depleted during the spawning and winter periods.

During the winter months of 1998 and 1999, both the relative (HSI) and absolute mass of the digestive gland consistently showed a substantial reduction (Figs. 1C \& 3), strongly suggesting that external food supplies could not meet the energy demands of Laternula elliptica during the prolonged winter period. Under starvation conditions, storage products in the liver or digestive gland are liberated to fuel metabolic processes, causing a sharp decrease in the HSI. The positive correlations of the HSI and absolute mass values of the digestive gland with chlorophyll strongly support this interpretation. Brockington (2001) reported that L. elliptica ceased feeding for about 4 mo during the winter, and attributed this to the absence of microsized phytoplankton cells in the water column and also to lack of sediment resuspension under fast ice. Apart from the digestive gland, a considerable amount of mass was also lost from the muscle tissues (Fig. 3, Table 3 ). The muscle and digestive gland thus seem to serve as energy depots for maintenance metabolism under starvation conditions.

It is also noteworthy that the mass lost from muscle tissue was much greater in 1999, while the absolute amount of mass lost from the digestive gland was almost the same in the 2 winter periods (Table 3 ). This may indicate that the major energy source, as well as the total amount of energy reserves depleted, can vary depending on the severity of the food shortage during the winter. It is likely that the energy reserves in the digestive gland are used up first for maintenance during the winter, with further use of energy substrates (taken mostly from muscle tissues) occuring under harsher and more persistent starvation conditions. A similar phenomenon has been reported for the Antarctic sea urchin Sterechinus neumayeri in the Antarctic Peninsula region by Brockington et al. (2001), who observed a significant decrease in gut-tissue mass in early winter, and a progressive reduction in body-wall organic mass later in the winter. Other previous research has shown that marine bivalves and other echinoids may use muscle parts as long-term energy depots and the gut as a short-term energy store (Lares \& Pomory 1998).

Apart from maintenance metabolism, there is an additional energy demand for gonad development during the winter. Gonad mass continued to increase in the winter parallel to oocyte development, while the other tissue masses were decreasing; this suggests that gonad development proceeds at the expense of energy reserves stored in somatic tissues such as the muscle and digestive gland (Figs. 1C \& 3). Comely (1974) found that the gonads of the scallop Pecten maximus also increased during the winter, while other tissue masses and their reserves decreased. Somatic growth and reproduction are competing for resources, and the partitioning of energy between these 2 processes is an important trait of the life history of marine bivalves (Strohmeier et al. 2000).

The overall body mass reduction of Laternula elliptica, even during the harsher winter, was $\sim 24 \%$ of total $\mathrm{AFDM}_{\text {; }}$ this seems less pronounced than that in some temperate bivalves, which undergo a large wintermass loss (Ansell 1974, Zandee et al. 1980, Beninger \& Lucas 1984, Honkoop \& Beukema 1997). This may be attributable, at least in part, to reduced metabolic rates, which are several times lower in L. elliptica than in temperate bivalves (Ahn \& Shim 1998, Brockington 2001). Brockington (2001) has further shown that the metabolic rate of L. elliptica is 3 times lower during the winter than during the summer, and suggested that starvation during the winter may be less harsh in the Antarctic than in temperate waters, as a smaller amount of energy would be needed for survival in the former habitat. Higher body mass reduction due to higher metabolic costs was reported from some temperate bivalves during warmer winter, by Honkoop \& Beukema (1997).

\section{Protein use as an overwintering strategy of Laternula elliptica}

Laternula elliptica probably uses protein as the major energy substrate for maintenance metabolism under prolonged starvation conditions. Protein comprised $>50 \%$ of AFDM lost between March and June 1998 and $>70 \%$ during the corresponding period of 1999, suggesting that a greater portion of protein is used during harsher winters. Brockington (2001) also reported that O:N ratios estimated from metabolism data of this species in the Ross Sea indicated proteinbased metabolism. Use of protein as a major energy source may be attributable in part to the morphological features of L. elliptica, whose muscular tissues comprise nearly half of the total soft-tissue mass. Protein loss was most substantial ( $70 \%$ of total protein loss) in the muscle, particularly during the harsher winter months of 1999. In particular, a striking morphological feature of L. elliptica is its siphons, which comprise $\sim 80 \%$ of all muscle tissues. In a parallel study, Kim (2002) found for the L. elliptica siphon that a content of 60 to $120 \mathrm{kDa}$ protein recorded in January $1999 \mathrm{had}$ 
dropped by $80 \%$ in October 1999; this is consistent with the trend seen in the protein content in the present study.

Laternula elliptica is 1 of only 2 large bivalves in Antarctic waters. The other large bivalve, the scallop Adamussium colbecki, also has a large proportion of adductor muscle tissues. Both species are among the most abundant and widely distributed benthic fauna in shallow Antarctic waters. Common temperate bivalves, i.e. mussels and oysters, which contain a relatively small percentage of muscular tissues, are absent from Antarctic waters. All other Antarctic bivalves are relatively small. Although the seasonal energetics of $A$. colbecki are unknown, the results from this and previous studies on L. elliptica could indicate that successful adaptation of these large filterfeeding bivalves to extremely seasonal food availability is related in part to the capacity of their muscle tissues to store large portions of protein in preparation for a prolonged period (up to $9 \mathrm{mo}$ ) of food shortage. Protein use as a major energy source has also been reported in a temperate scallop species, Pecten maximus (Strohmeier et al. 2000), which also has a large proportion of adductor muscle. Thus, protein use, with muscle tissues as a depot for protein reserves, may be a result of selective mechanisms of Antarctic marine herbivores to enable them to survive prolonged periods of food-limitation in Antarctic waters.

Acknowledgements. We would like to thank the divers Mr. Hyunsoo Kim and Mr. Sungsoo Han, who collected the clams at the King Sejong Station. This work was carried out as part of the Korean Antarctic Research Program with the support of the Korean Ocean Research \& Development Institute.

\section{LITERATURE CITED}

Ahn IY (1993) Enhanced particle flux through the biodeposition by the Antarctic suspension-feeding bivalve Laternula elliptica in Marian Cove, King George Island. J Exp Mar Biol Ecol 171:75-90

Ahn IY (1994) Ecology of the Antarctic bivalve Laternula elliptica (King and Broderip) in Collins Harbor, King George Island: benthic environment and an adaptive strategy. Mem Natl Instt Polar Res (Tokyo) Spec Issue 50:1-10

Ahn IY (1997a) Feeding ecology of the Antarctic lamellibranch Laternula elliptica (Laternulidae) in Marian Cove and vicinity, King George Island during one austral summer. In: Battaglia B, Valencia J, Walton DW (eds) Antarctic communities: species, structure and survival. Cambridge University Press, London, p 142-151

Ahn IY (1997b) Some ecological and physiological strategies for energy conservation of the Antarctic clam, Laternula elliptica. Korean J Polar Res 8:77-83

Ahn IY, Shim JH (1998) Summer metabolism of the Antarctic clam Laternula elliptica in Maxwell Bay, King George Island and its implications. J Exp Mar Biol Ecol 224:253-264 Ahn IY, Chung H, Kang JS, Kang SH (1997) Diatom composi- tion and biomass variability in nearshore waters of Maxwell Bay, Antarctica, during the 1992/1993 austral summer. Polar Biol 17:123-130

Ahn IY, Cho KW, Choi KS, Seo Y, Shin J (2000) Lipid content and composition of the Antarctic lamellibranch, Laternula elliptica (King and Broderip) (Anomalodestmata: Laternulidae) in King George Island during an austral summer. Polar Biol 23:24-33

Ahn IY, Chung H, Choi KS (2001) Some ecological and physiological features of the Antarctic clam Laternula elliptica (King and Broderip) in a nearshore habitat on King George Island. Ocean Polar Res 23:419-424

Ansell AD (1974) Seasonal changes in biochemical composition of the bivalve chlamys septemradiata from the Clyde Sea area. Mar Biol 25:85-99

Beninger PG, Lucas A (1984) Seasonal variation in condition, reproductive activity, and gross biochemical composition of two species of adult clam reared in a common habitat: Tapes decussatus L. (Jeffreys) and Tapes philippinarum (Adams and Reeve). J Exp Mar Biol Ecol 79:19-37

Beukema JJ, De Bruin W (1977) Seasonal changes in dry weight and chemical composition of the soft parts of the tellinid bivalve Macoma balthica in the Dutch Wadden Sea. Neth J Sea Res 11:42-55

Bigatti G, Penchaszadeh PE, Mercuri G (2001) Aspects of the gonadal cycle in the Antarctic bivalve Laternula elliptica. J Shellfish Res 30:283-287

Brey T, Mackensen A (1997) Stable isotopes prove shell growth bands in the Antarctic bivalve Laternula elliptica to be formed annually. Polar Biol 17:465-468

Brockington S (2001) The seasonal energetics of the Antarctic bivalve Laternula elliptica (King and Broderip) at Rothera Point, Adelaide Island. Polar Biol 24:523-530

Brockington S, Clarke A, Chapman ALG (2001) Seasonality of feeding and nutritional status during the austral winter in the Antarctic sea urchin Sterechinus neumayeri. Mar Biol 139:127-138

Cattaneo-Vietti R, Chiantore M, Schiaparelli S, Albertelli G (2000) Shallow- and deep-water mollusc distribution at Terra Nova Bay (Ross Sea, Antarctica). Polar Biol 23:173-182

Chang KI, Jun HK, Park GT, So YS (1990) Oceanographic conditions of Maxwell Bay, King George Island, Antarctica (austral summer 1989). Korean J Polar Res 1:27-46

Clarke A (1983) Life in cold water: the physiological ecology of polar marine ectotherms. Oceanogr Mar Biol Annu Rev 21:341-453

Clarke A (1984) Lipid composition of two species of Serolis (Crustacea, Isopoda) from Antarctica. Br Antarct Surv Bull 64:37-53

Clarke A (1988) Seasonality in the Antarctic marine environment. Comp Biochem Physiol B90:461-473

Clarke A (1996) Marine benthic populations in Antarctica: patterns and processes. Antarct Res Ser 70:373-388

Clarke A (2001) Benthic organisms and environmental variability in Antarctica: responses to seasonal, decadal and long-term change. Ocean Polar Res 23:433-440

Clarke A, Leakey RJG (1996) The seasonal cycle of phytoplankton, macronutrients, and the microbial community in a nearshore Antarctic marine ecosystem. Limnol Oceanogr 41:1281-1294

Clarke A, Peck LS (1991) The physiology of polar marine zooplankton. Polar Res 10:355-369

Clarke A, Holms LJ, White MG (1988) The annual cycle of temperature, chlorophyll and major nutrients at Signy Island, South Orkney Islands, 1969-1982. Br Antarct Surv Bull 80:65-86

Comely CA (1974) Seasonal variations in the flesh weights 
and biochemical content of the scallop Pecten maximus L. in the Clyde Sea area. J Cons Int Explor Mer 35:281-295

Davis JP, Wilson JG (1983) Seasonal changes in tissue weight and biochemical composition of the bivalve Nucula turgida in Dublin Bay with reference to gametogenesis. Neth J Sea Res 17:84-95

Dayton PK (1989) Interdecadal variation in an Antarctic sponge and its predators from oceanographic climate shifts. Science 245:1484-1486

De Moreno JEA, Moreno VJ, Brenner RR (1976) Lipid metabolism of the yellowclam Mesodesma mactroides: I. Composition of the lipids. Lipids 11:334-340

De Zwaan A, Zandee DI (1972) Body distribution and seasonal changes in the glycogen content of the common sea mussel Mytilus edulis. Comp Biochem Physiol A43:53-58

Folch J, Lees M, Sloane-Stanley GH (1957) A simple method for the isolation and purification of total lipids from animal tissues. J Biol Chem 226:497-509

Gabbott PA (1983) Developmental and seasonal metabolic activities in marine molluscs. In: Hochachka PW, Wilbur KM (eds) The Mollusca, Vol 2. Environmental biochemistry and physiology. Academic Press, New York, p 165-217

Gosling E (1992) The mussel Mytilus: ecology, physiology, genetics and culture. Elsevier, Amsterdam

Grebmeier JM, Barry JP (1991) The influence of oceanographic processes on pelagic-benthic coupling in polar regions: a benthic perspective. J Mar Syst 2:495-518

Hardy P (1972) Biomass estimates from some shallow-water infaunal communities at Signy Island, South Orkney Island. Br Antarct Surv Bull 31:93-106

Honkoop PJC, Beukema JJ (1997) Loss of body mass in winter in three intertidal bivalve species: an experimental and observational study of interacting effects between water temperature, feeding time and feeding behaviour. J Exp Mar Biol Ecol 212:277-297

Kang SH, Kang JS, Chung KH, Lee MY, Lee BY, Chung H, Kim Y, Kim DY (1997) Seasonal variation of nearshore Antarctic microalgae and environmental factors in Marian Cove, King George Island, 1996. Korean J Polar Res 8: $9-27$

Kang JS, Kang SH, Lee JH, Lee SH (2002) Seasonal variation of microalgal assemblages at a fixed station in King George Island, Antarctica, 1996. Mar Ecol Prog Ser 229: 19-32

Keppler D, Decker K (1984) Glycogen. In: Bergmeyer HU, Bergmeyer J, Graßi M (eds) Methods of enzymatic analysis, Vol VI. Metabolites 1: carbohydrates. Verlag Chemie, Weinheim, p 11-18

Kim HC (1996) The variations of phytoplankton biomass, bacterial biomass and primary productivity in Maxwell Bay, South Shetland Islands, Antarctica. MS thesis, Seoul National University, Seoul

Kim KW (2002) Proteomic analysis of the Antarctic bivalve Laternula elliptica (Anomalodesmata: Laternulidae) in response to seasonal variation and cadmium exposure. MS thesis, Hanyang University, Ansan

Klingensmith JS, Stillway LW (1982) Lipid composition of selected tissues of the hardshell clam Mercenaria mercenaria. Comp Biochem Physiol B71:111-112

KORDI (Korea Ocean Research \& Development Institute) (1997) Wintering report of the 9th Korea Antarctic Research Program at King Sejong Station (Dec 1995-Dec 1996). Ministry of Maritime Affairs and Fisheries, Seoul

KORDI (Korea Ocean Research \& Development Institute) (1999) The studies on natural environment and conser-

Editorial responsibility: Otto Kinne (Editor), Oldendorf/Luhe, Germany vation of polar region. ECPP 99001-03. Korea Ocean Research \& Development Institute, Seoul

KORDI (Korea Ocean Research \& Development Institute) (2000) Annual report of environmental monitoring on human impacts at the King Sejong Station. ECPP 0000102. Korea Ocean Research \& Development Institute, Seoul

Lares MT, Pomory CM (1998) Use of body components during starvation in Lytechinus variegatus (Lamarck) (Echinodermata: Echinoidea). J Exp Mar Biol Ecol 225:99-106

Mercuri G, Iken K, Ledesma B, Dubois RF (1998) On the distribution patterns and density of the Antarctic infaunal bivalve Laternula elliptica in Potter Cove, King George Island. In: Wiencke C, Ferreyra G, Arntz W, Rinaldi C (eds) The Potter Cove coastal ecosystem, Antarctica. Ber Polarforsch, p 137-143

Murphy EJ, Clarke A, Symon C, Priddle J (1995) Temporal variation in Antarctic sea-ice: analysis of a long-term fastice record from the South Orkney Islands. Deep-Sea Res 42:1045-1062

Pearse JS, Giese AC (1966a) Food, reproduction and organic constitution of the common Antarctic echinoid Sterechinus neumayeri (Meissner). Biol Bull (Woods Hole) 130: 387-401

Pearse JS, Giese AC (1966b) The organic constitution of several benthonic invertebrates from McMurdo Sound, Antarctica. Comp Biochem Physiol 18:47-57

Peck LS, Clarke A, Holms LJ (1987) Summer metabolism and seasonal changes in biochemical composition of the Antarctic brachiopod Liothyrella uva (Broderip, 1833). J Exp Mar Biol Ecol 114:85-97

Peck LS, Colman JG, Murray AWA (2000) Growth and tissue mass cycles in the infaunal bivalve Yoldia eightsi at Signy Island, Antarctica. Polar Biol 23:420-428

Pieters H, Kluytmans JH, Zandee DI, Cadee GC (1980) Tissue composition and reproduction of Mytilus edulis in relation to food availability. Neth J Sea Res 14:349-361

Pollero RJ, Re ME, Brenner RR (1979) Seasonal changes of the lipids of the mollusc Chlamys tehuelcha. Comp Biochem Physiol A64:257-263

Saborowski R, Buchholz F (1996) Annual changes in the nutritive state of North Sea dab. J Fish Biol 49:173-194

Shim JH (2001) Biogeochemical cycle of elements (C, N, P, Si, metals) at a subtidal benthic environment of the Marian Cove, King George Island, Antarctica. PhD thesis, Inha University, Incheon

Stanwell-Smith D, Clarke A (1998) Seasonality of reproduction in the cushion star Odontaster validus at Signy Island, Antarctica. Mar Biol 131:479-487

Stout WE, Shabica SV (1970) Marine ecological studies at Palmer Station and vicinity, Antarct J US 5:134-135

Strohmeier T, Duinker A, Lie Ø (2000) Seasonal variations in chemical composition of the female gonad and storage organs in Pecten maximus (L.) suggesting that somatic and reproductive growth are separated in time. J Shellfish Res 19:741-747

Urban HJ, Mercuri G (1998) Population dynamics of the bivalve Laternula elliptica from Potter Cove, King George Island, South Shetland Islands. Antarct Sci 10:153-160

Wenne R, Polak L (1989) Lipid composition and storage in the tissues of the bivalve, Macoma balthica. Biochem Syst Ecol 17:583-587

Zandee DI, Kluytmans JH, Zurburg W, Pieters H (1980) Seasonal variations in biochemical composition of Mytilus edulis with reference to energy metabolism and gametogenesis. Neth J Sea Res 14:1-29

Submitted: February 14, 2003; Accepted: May 6, 2003

Proofs received from author(s): July 11, 2003 